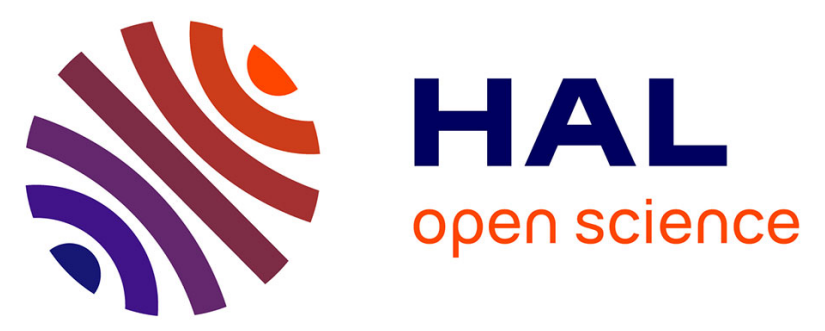

\title{
Transportation Management and Decision Support Systems within the Supply Chain Management Framework
}

Issam Moghrabi, Fatemah O. Ebrahim

\section{> To cite this version:}

Issam Moghrabi, Fatemah O. Ebrahim. Transportation Management and Decision Support Systems within the Supply Chain Management Framework. 17th Conference on e-Business, e-Services and e-Society (I3E), Oct 2018, Kuwait City, Kuwait. pp.337-343, 10.1007/978-3-030-02131-3_30 . hal02274167

\section{HAL Id: hal-02274167 \\ https://hal.inria.fr/hal-02274167}

Submitted on 29 Aug 2019

HAL is a multi-disciplinary open access archive for the deposit and dissemination of scientific research documents, whether they are published or not. The documents may come from teaching and research institutions in France or abroad, or from public or private research centers.
L'archive ouverte pluridisciplinaire HAL, est destinée au dépôt et à la diffusion de documents scientifiques de niveau recherche, publiés ou non, émanant des établissements d'enseignement et de recherche français ou étrangers, des laboratoires publics ou privés. 


\title{
Transportation Management and Decision Support Systems within the Supply chain management framework
}

\author{
Issam A.R. Moghrabi ${ }^{[0000-0002-4517-7630]}$ and Fatemah O. Ebrahim \\ College of Business Administration \\ Gulf University for Science and Technology \\ Kuwait \\ moughrabi.i@gust.edu.kw
}

\begin{abstract}
With technology and globalization, supply chain expanded and therefore supporting software is required in order to ensure prompt decisions are appropriately made. The emphasis of this paper is on the transportation management system (TPS) that supports the decision making process within the supply chain management framework. Our hypothesis focuses on the routing and mapping module within TPS. To support the hypothesis, questionnaires were distributed to the managers of small scale businesses in Al-Shuwaikh commercial district in Kuwait and the results obtained helped rank the importance of four carefully selected modules embraced by transportation management systems. A methodical regression analysis approach was used to substantiate the findings as elucidated in the study presented here.
\end{abstract}

Keywords: supply chain management, transportation management system, Decision Support Systems.

\section{Introduction}

Supply chain management is the management of the flow of goods and services, which include raw material supply, production and services, inventory management and goods delivery till it reach to the customers [1]. As per the definition, it is obvious that supply chain role is highly correlated to other roles and functions within the same organization and externally. Within the organization there should be strong integration with the production/operation module, information technology, marketing and procurement. External links will be with suppliers, customers and probably shipping companies if this is not part of the organization. Information technology can effectively support the globalization of the supply chain management process in many different ways where no manager's insight or a simple calculation process can be sufficient for making optimal or near-optimal business decisions. With globalization, there is an expansion of supply chains beyond any traditional boundaries and this incurs harder supply chain management decisions. In general, the supplier will focus on cost effectiveness, sufficient quantity of production, and sustaining quality during production. Also, while delivering to customers, committed time of delivery gains much signifi- 
cance due to its contribution to reaching the ultimate goal of the business in terms of gaining revenue, customer satisfaction, loyalty and building brand and good reputation [1].

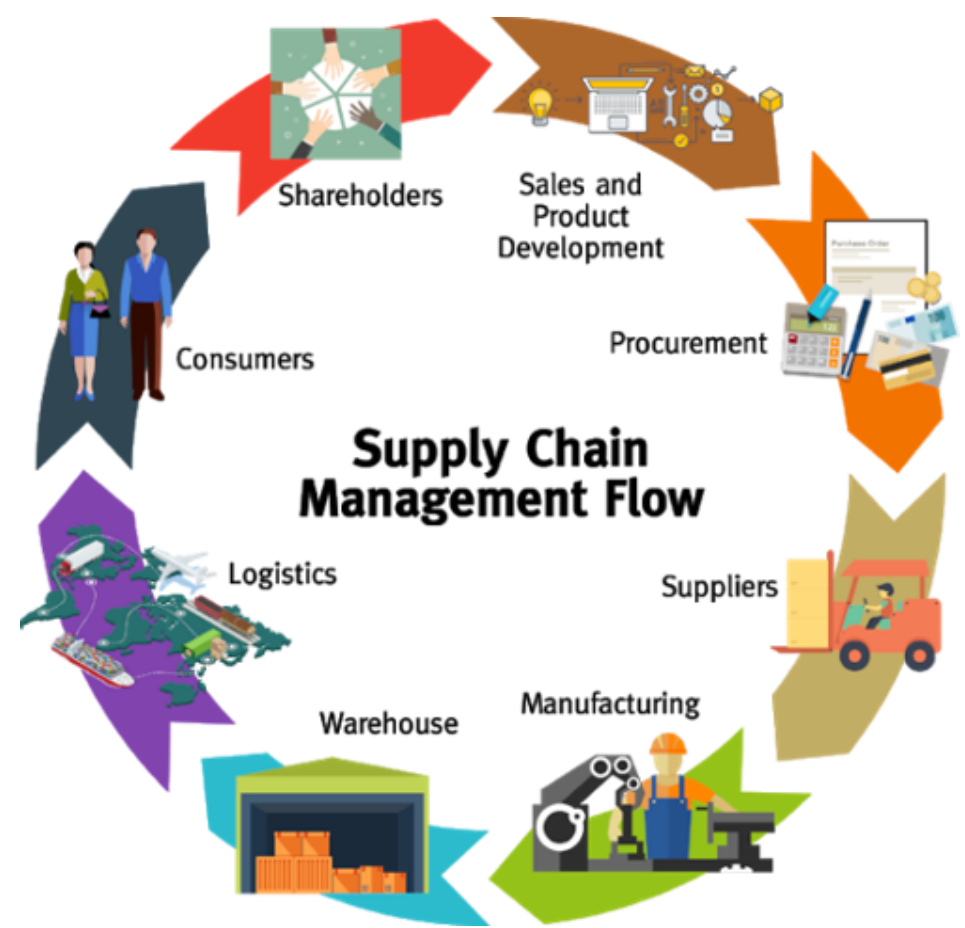

Fig. 1. Supply Chain Management Flow [2].

During the supply chain management flow (Fig. 1), there should be a system to bring out the best outcome of each any every stage such that maximizing revenue, gaining customer satisfaction and optimizing the cost. Information systems help to achieve these outcomes effectively [2]. It would be even more effective if there is an integrated supply chain management system to gather all the stages and take decisions based on the biggest picture considering all inputs and external factors as well.

In order to have effective supply chain management, it is essential to have integrated supply chain business processes [1]. Integration includes collaborative work between buyers and suppliers, product development, common systems, and shared information. This cannot be achieved without information systems. The intricate choice of supply chain management systems is dependent on many parameters, such as business size, business culture in term of willingness to adapt technology and the outcome required from this system [5]. Some systems focus on cost optimization, others on customer satisfaction and many of them help in finding the optimum decisions and solutions. In short, supply chain management systems aim to help in completing the 
business process effectively. Modules for supply chain management software include customer requirement processing, purchase order processing, sales and distribution, inventory management, goods receipt and warehouse management, supplier management/sourcing and transportation management. In this article, the focus will be on Transportation management system processes.

\section{Transportation Management system}

The emphasis of Transportation Management system (TMS) is on the transportation logistics that support the supply of products or services while minimizing both cost and time. TMS comprises several processes that interact to fulfill the overall functionality intended by the system (see figure 2). To emphasize the significance of the TMS, many authors $[2,6,8,17]$ pointed out that usually transportation cost consumes between 20 to $35 \%$ of the total production and logistics costs of a product. Therefore, any achievable savings in transportation cost will be likely to result in nontrivial savings on the overall production cost and related logistics.

The significance of transportation is mounting at a fast pace as the delivery channels are moving from national to international confines [6]. The dire need today is for good quality commodities at decreasing maintenance costs to ensure availability and robustness of items. Further, a powerful transportation module is essential for lessening costs through better path arranging, load enhancement, carrier, enhanced traceability across the transportation chain, offering options for improving in the transportation plan and supply chain execution. [](Black, 2001). Transport influences the production, logistical practices and delivery planning.

This study aims to determine the rankings of the variables/processes of the transportation Management system in terms of importance. There are many processes embedded within TMS such as tracking, vehicle maintenance, fuel costing, warehousing communications, EDI implementations, accounting, traveler and cargo handling, inbound and outbound transportation mode, vehicle load, shipment batching of orders, scheme simulation, cost controls, optimizing terrestrial transport rounds, freight audit and payment, yard management, order visibility, carrier management, advanced shipping and many others. Yet this study will focus on only four processes since the firms considered in this study are small businesses in Kuwait and for which more functions are either not needed or do not have any added value for the business [9]. The four processes are routing \& mapping, transportation cost \&service quality, carrier selection \&management, and real time tracking. The results obtained are likely to vary for different firm sizes. 


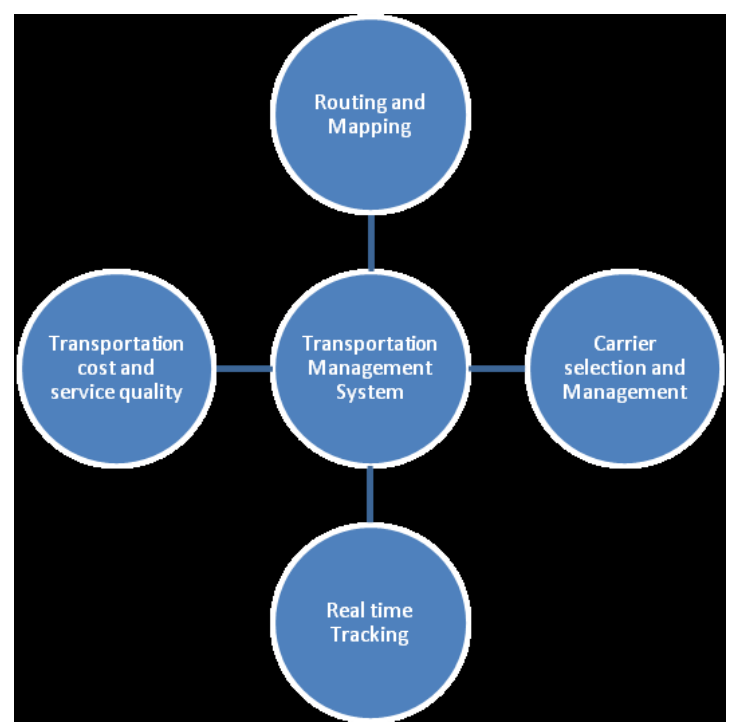

Fig. 2. Functions Performed by Transportation Management System

\section{Research Hypothesis}

Our hypothesis formulation assumes that Routing and Mapping is the most influential parameter of the TMS for small scale firms [9,11]. The research instrument was a a questionnaire which embodies ranking questions and five -point Likert scale, where 1 indicates a strongly disagree and 5 denotes a strongly agree. Data was collected from different small scale firms in the Industrial area of Al-Shuwaikh in Kuwait in order to check the validity of the assumption in our hypothesis. The questionnaire was distributed to 57 managers in many business sectors such as car parts, supermarkets, meat preparation and packaging companies, plumbing supplies, restaurants, fast food, Varnish and Paint, furniture and others. All the questionnaires results were considered and regression analysis was applied and as a result is the hypothesis of Transportation management system ensures proper routing and mapping of the stock in small scale firms is acceptable. Thus, the following is the main hypothesis of the study:

Hypothesis: Transportation management system guarantees the optimal routing of products in small size businesses.

Objective: The objective is to study whether transportation management systems guarantees the optimal routing of products in small size businesses. 


\section{Data Analysis and Results Interpretation}

To facilitate the analysis of the collected data and the interpretation of the results, a ranking table as well as linear regression are employed. The averages computed from the data collected from the study through the managers of the respective firms are tabulated in Table 1. The Table has in the first column the business categories to which the questionnaire was channeled. The numbers in the parentheses in that column indicate the count of the businesses participating in the study that fall under that specific business category. The last 4 columns to the right list the various processes a typical transportation management system performs. The numbers reported in the rows indicate the average score given to each process for each business category ( 5 indicates highest and 1 is for lowest). The roman letters in the four columns to the right denote the rank/importance of the function for a particular business category.

\begin{tabular}{|c|l|l|l|c|}
\hline Units/Factors & $\begin{array}{l}\text { Transport } \\
\text { cost and Ser- } \\
\text { vice Quality } \\
\text { and } \\
\text { Mapping }\end{array}$ & $\begin{array}{l}\text { Routing } \\
\text { Selection } \\
\text { and } \\
\text { Management }\end{array}$ & $\begin{array}{l}\text { Real time } \\
\text { Tracking }\end{array}$ \\
\hline $\begin{array}{c}\text { meat preparation and } \\
\text { packaging (7) }\end{array}$ & $4(\mathrm{I})$ & $3.3(\mathrm{II})$ & $3(\mathrm{III})$ & $1(\mathrm{IV})$ \\
\hline car parts (8) & $3.2(\mathrm{I})$ & $2(\mathrm{III})$ & $1.8(\mathrm{I})$ & $2.6(\mathrm{II})$ \\
\hline Restaurants (10) & $3(\mathrm{III})$ & $4.3(\mathrm{I})$ & $3.3(\mathrm{II})$ & $4(\mathrm{IV})$ \\
\hline fast food (9) & $4(\mathrm{II})$ & $5(\mathrm{I})$ & $3(\mathrm{III})$ & $4(\mathrm{IV})$ \\
\hline Varnish and Paint (6) & $3(\mathrm{III})$ & $4(\mathrm{I})$ & $3.5(\mathrm{II})$ & $1(\mathrm{IV})$ \\
\hline Furniture (5) & $3.8(\mathrm{II})$ & $4(\mathrm{I})$ & $3(\mathrm{III})$ & $3(\mathrm{IV})$ \\
\hline Marble (3) & $2.6(\mathrm{II})$ & $3(\mathrm{I})$ & $2.2(\mathrm{III})$ & $1(\mathrm{IV})$ \\
\hline Coffee shops (7) & $3(\mathrm{II})$ & $3.8(\mathrm{I})$ & $2.7(\mathrm{III})$ & $2(\mathrm{IV})$ \\
\hline Electronics & $3.3(\mathrm{II})$ & $3.4(\mathrm{I})$ & $3.1(\mathrm{III})$ & $2.1(\mathrm{IV})$ \\
\hline $\begin{array}{c}\text { Others } \text { Miscellane- } \\
\text { ous) (2) }\end{array}$ & $2.1(\mathrm{III})$ & $3.6(\mathrm{I})$ & $3(\mathrm{II})$ & $2.3(\mathrm{IV})$ \\
\hline $\begin{array}{c}\text { Mean \& } \\
\text { Rank }\end{array}$ & $\begin{array}{l}\text { 3.2 } \\
\text { (II) }\end{array}$ & $\begin{array}{l}\text { (I) } \\
\text { (I) }\end{array}$ & $\begin{array}{l}2.86 \\
\text { (III) }\end{array}$ & $\begin{array}{l}\text { (IV) } \\
\text { (IV) }\end{array}$ \\
\hline
\end{tabular}

Table 1. Functions Performed by Transportation Management System in Small Scale Industries

The results tabulated in Table 1 indicate that to the most of the businesses included in this study, Routing and Mapping is the most significant module in a typical TMS. 


\section{$5 \quad$ Regression Analysis Results}

Regression analysis was used for testing our research hypothesis. The results of the analysis are reported in Table 2 . The $\mathrm{R}$ value that came up indicates a $68 \%$ correlation between the independent variable, namely Transportation Management System, and the dependent one Routing and mapping. In addition, the R2 value denotes that the Transportation Management System can be used to justify a $63 \%$ variation in Routing and mapping. The adjusted $0.601 \mathrm{R} 2$ value reported predicts an increase in the R2 value whenever another independent variable is also considered. The obtained value of $\beta$ is a shows the strong kinship between the dependent and the independent variables. Significant changes in R square are found with F-values significant at 5\% confidence level. Thus the hypothesis "Transportation management system guarantees the optimal routing of products in small size businesses." is acceptably good with a significance level of $\mathrm{p}<.06$.

\begin{tabular}{|c|c|c|c|c|c|c|c|c|c|}
\hline $\begin{array}{l}\overline{0} \\
\stackrel{0}{\Sigma}\end{array}$ & $\mathrm{R}$ & $\mathrm{R} 2$ & 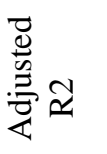 & 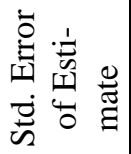 & 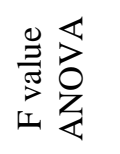 & $\dot{\infty} \overrightarrow{\bar{D}} \overline{\vec{\omega}}$ & $\beta$ & $\mathrm{t}$ & 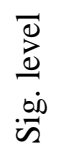 \\
\hline 1. & .688 & .632 & .601 & .1791 & 32.266 & .000 & .658 & 8.8 & .018 \\
\hline
\end{tabular}

Table 2: Regression Model Summary

\section{$6 \quad$ Study Limitations}

Although this study went through methodical statistical analysis, the data sampled is taken from a specific industrial area. Thus, it can be argued that the results cannot be generalized to cover the whole of Kuwait. Despite the limitation of the sample, we strongly believe, based on our experience in Kuwait, that Al-Shwaikh Area is a typical commercial district that is replicated in different locations within the country. The results obtained from the study originate from the human input collected, a highly subjective source. However, this seems to be the sole source we rely on. We do not believe that this weakens the findings as similar consistent results were obtained in []. Another limitation of the study is considering only small firms in Kuwait. However, this is the focus of the study presented here. 


\section{Conclusion}

Supply chain management systems are usually offline tools can help improve the supply chain from many aspects, such as: supply calculation, demand forecasting, supply chain planning, supply chain scheduling, raw material distribution, supply chain optimization systems, such as transportation management, among others. The study presented here aims to highlight the significance of the Transportation Management Systems within the supply chain framework as one of the most important modules due to the cost factor involved. In specific, the study hypothesis and the results achieved confirm that the emphasis is to be placed on the Routing and Mapping module within TMS in small scale businesses. The output of our study divulges the average ranking of the processes performed by transportation management systems in small businesses in the Al-Shuwaikh Commercial Area in Kuwait. Among the numerous modules involved in TMS, the ranking presented in the study considers the most prominent and effective modules, namely "Transportation cost and service quality", "Routing and mapping", "Carrier selection and management", and "Real time Tracking". The variable "Routing and mapping" ranked first in terms of the determination of an optimal transportation and routing plan. In addition, regression analysis was utilized to confirm the research hypothesis "Transportation management system guarantees the optimal routing of products in small size businesses" with encouraging results.

\section{References}

1. Azadfallah, M. in , "A New Aggregation Rule for Ranking Suppliers in Group Decision Making under Multiple Criteria”, ”, Journal of Supply Chain Management Systems, V. 5, 4, 38-49, (2016).

2. Basheer, S., Srinivasan, K.K. \& Sivanandan, R., Transp. in Dev. Econ. 4: 8. https://doi.org/10.1007/s40890-018-0061-5, (2018).

3. Black, W. R.. An unpopular essay on transportation. Journal of Transport Geography, 9, 1-11, (2001).

4. Caputo, A., Pelagagge, P., Scacchia, F., Integrating transport systems in supply chain management software tools, Industrial Management \& Data Systems, Vol. 103 Issue: 7, pp.503-515, https://doi.org/10.1108/02635570310489205, .(2003).

5. Chalotra, V. and Kumar, P., "Transportation Management System Functions and Performance Amplifying the Span of Small Scale Firms", Journal of Supply Chain Management Systems, V. 5, 4, (2016).

6. Ebrahimnejad, A. Note on "A fuzzy approach to transport optimization problem", Optim Eng 17: 981. https://doi.org/10.1007/s11081-015-9277-y, (2016).

7. Kalakota R., Whinston A.B., "Electronic commerce" in A manager's guide, USA: Addison Wesley, pp. 285-316, (1997).

8. Karmaker, C. L. , "A Decision Support System for Warehouse Location Selection: A Case Study", Journal of Supply Chain Management Systems, V. 5, 4, (2016). 
9. Kumar, N. R. Optimization of supply chain network modeling and performance measurement in flow of production, Journal of Supply Chain Management Systems, 3(4), 1-6, (2014).

10. Luo, X., \& Jennings, N. R. A spectrum of compromise aggregation operators for multiple attribute decision making. Artificial Intelligence, 171(2007), 161-184, (2007).

11. Pedersen, E. L., \& Gray, R. The transport selection criteria of Norwegian Exporters. International Journal of Physical Distribution \& Logistics Management, 28(2), 108, (1998).

12. Shahbandarzadeh, H., \& Haghighat, F. Evaluation of the strategies of target market selection on the basis of IFE and EFE matrixes using LINMAP technique. Iranian Journal of Management Studies (IJMS), 3(3), 41-58, (2010).

13. Triantaphyllou, E. (2000). Multi criteria decision making methods: A comparative study. Kluwer Academic Publishers.

14. Wang, Y. M., Yang, J. B., \& Xu, D. L. A preference aggregation method through the estimation of utility intervals. Computers \& Operations Research, 32(2005), 2027-2049, (2005).

15. Wedley, W. C., \& Choo, E. U. An analysis of AHP comparisons and priorities. ASAC, Hlifax, Nova Scotia, 16-28, (2008).

16. Zanakis, S. H., Solomon, A., Wishart, N., \& Dublish, S. Multi attribute decision making: A simulation comparisons of select methods. European Journal of Operational Research, 107(3), 507-529, (1998).

17. Yao, MJ. \& Hsu, H. A new spanning tree-based genetic algorithm for the design of multistage supply chain networks with nonlinear transportation costs, Optim Eng 10: 219. https://doi.org/10.1007/s11081-008-9059-x, (2009). 